\title{
PROTECTING THE STANDING OF RENEWAL SITE FAMILIES TO SEEK REVIEW OF COMMUNITY RELOCATION PLANNING
}

Is the Housing Acts of $1949^{1}$ and $1954,{ }^{2}$ Congress made federal funds available to communities attempting to attack urban decay. ${ }^{3}$ Title I, the core of this legislation, deals with urban redevelopment and renewal. ${ }^{4}$ Localities participating in the Title I program are urged to attack urban ills on several fronts : clearance and redevelopment of slum areas, rehabilitation of blighted neighborhoods, and conservation of existing sound neighborhoods. ${ }^{5}$ Each of these approaches involves the displacement of families living on renewal sites, and Congress has conditioned the award of federal funds for Title I projects on the existence of a community program to relocate displaced site families in standard housing; under section 105(c) of the 1949 Act, federal assistance contracts must require that decent, safe, and sanitary housing be available for all displaced families. ${ }^{6}$ Enforcement of this requirement is entrusted to the Housing Administrator, the highest official of the Housing and Home Finance

1. 63 Stat. 413 (1949), as amended, 42 U.S.C. $\$ \$ 1441-60$ (Supp. IV, 1962).

2. 68 Stat. 590 (1954), as amended, 42 U.S.C. $\$ \$ 1446-60$ (Supp. IV, 1962).

3. Federal grants are normally available on a 2-1 matching fund basis. 63 Stat. 416 (1949), as amended, 42 U.S.C. $\$ 1453$ (Supp. IV, 1962). In 1957, the Administrator was authorized to extend aid on a 3-1 basis, in limited circumstances. 71 Stat. 299 (1957), as amended, 42 U.S.C. § 1453 (Supp. IV, 1962).

4. In the 1949 Act, Title I encompassed the clearance and rebuilding of slum areas or redevelopment. 63 Stat. 414 (1949), as amended, 42 U.S.C. \$§ 1451-60 (Supp. IV, 1962). The limitations of the clearance approach were soon noted. See, e.g., Slayton, Urban Redevelopment Short of Clearance: Rehabilitation, Reconditioning, Conservation, and Code Enforcement in Local Programs, in Urban REDeveloparent: Problenss aND PrACTrCEs 313 (Woodbury ed. 1953) [hereinafter cited as WoodBuRY]. The renewal concept, introduced in the 1954 act, encourages the use of a variety of planning techniques.

5. The scope of the several renewal techniques is suggested in Johnstone, The Federal Urban Renewal Program, 25 U. CHI. L. Rev. 301 n.2 (1958). Professor Johnstone's article is an informative general survey of the federal program.

6. 63 Stat. 416 (1949), as amended, 42 U.S.C. \$ 1455(c) (1958). Section 105 (c) provides:

Contracts for loans or capital grants ... shall require that $-\ldots$.

(c) There be a feasible means for the temporary relocation of families displaced from the urban renewal area, and that there are or are being provided, in the urban renewal area or in other areas not generally less desirable in regard to public utilities and public and commercial facilities and at rents or prices within the financial means of the families displaced from the urban renewal area, decent, safe, and sanitary dwellings equal in number to the number of and available to such displaced families and reasonably accessible to their places of employment.

The statute requires only the relocation of families, and this Note is limited to problems of family relocation. The local community may, of course, assist displaced businessmen and individuals, and the statute permits the payment of moving expenses to such persons. 70 Stat. 1100 (1956), as amended, 42 U.S.C. $\$ 1456$ (f) (Supp. IV, 1962). The impact of renewal on neighborhood businessmen, and suggested ways to alleviate their burden, are discussed in. Spieger, The Forgotten MaN in Housing 48-51 (1959). 
Agency (HHFA). ${ }^{7}$ Under administrative regulations adopted by the HHFA pursuant to section 105 (c), a community is deemed eligible for renewal funds only when it has demonstrated the existence of both housing resources sufficient to meet the needs of relocation and an organization to assist displaced families through provision of referral and inspection services. ${ }^{8}$ By a network of provisions, then, the federal law seeks to insure that communities take steps to minimize the disruptive effects of renewal activity on site families. ${ }^{9}$

The community's task of relocation is not an easy one. More than 127,000 families had been displaced by renewal activity through $1961 ;^{10}$ and it was estimated that one million more families would be displaced in the decade following. ${ }^{11}$ This displacement is occurring at a time of serious national housing shortage ; $; 2$ the resulting widespread blight-over 25 million Americans, it has

7. 68 Stat. 624 (1954), as amended, 42 U.S.C. \$ 1451(c) (Supp. IV, 1962). The Administrator may not delegate his responsibility to review relocation planning, his duty to determine whether a community's workable program (see note 54 infra) is adequate, or his authority to certify that the renewal community qualifies for federal assistance. His other responsibilities in administering Title I may be delegated. 63 Stat. 417 (1949), 42 U.S.C. \& 1456(a)(1) (1958). In 1954, the Administrator delegated all other urban renewal functions to the Urban Renewal Administration, under the general supervision of a commissioner. HHFA Administrator's Reorganization Order No. 1, 19 Fed. Reg. 930304 (1954).

8. This standard emerges from a study of the information required by the HHFA to be submitted in documentation of the community's relocation planning. See generally HHFA, Urban Renewal Mandaz pt. 16, "Relocation" (1962). [The URban Renewal MANUAL is hereinafter cited as HHFA, URM.] The submission requirements are examined infra. See notes 50-59 and accompanying text.

9. In reporting favorably on the 1949 Bill, the Senate Committee observed, under the heading "Local Responsibility" :

The Bill sets up adequate safeguards against any undue hardship resulting from the undertaking of slum clearance under current conditions. It requires . . . that no slum-clearance project shall be undertaken by a local public agency unless there is a feasible means for the temporary relocation of the families to be displaced, and unless adequate permanent housing is available or is being made available to them.

S. REP. No. 84, to accompany S. 1070, 81st Cong., 1st Sess. 14 (1949).

10. hHFA, Relocation from Urban Renewal Projecr Areas Through DecearBER, 19619 (1962) [hereinafter cited as HHFA, ReLocation DATA].

11. Estimate of William I. Slayton, Urban Renewal Commissioner, reported in Relocation Revisions Released by URA, 19 J. Housing 248 (1962).

12. In 1949, the Senate Committee reported that the country should be prepared to build or rehabilitate an average of 1,300,000 non-farm dwellings in each of the next 12 years (i.e. through 1961) if there was to be progress towards the goal of better housing conditions for American families. S. REP. No. 84, to accompany S. 1070, 81st Cong., 1st Sess. 5 (1949). By 1960, the need, rather than decreasing, had increased to a point where construction of two million dwellings per year through 1970 was necessary to accommodate the increasing population and to replace exhausted units. Wurster, Framezvork for an Urban Society, in President's Comm'N on National Goals, Goals for Americans 225 (1960). New York City had a housing deficit of 430,000 dwelling units in 1958, yet the city's annual rate of construction was only 20,000 units. PANUCH, RElocation in New York City: Spectal Report to Mayor Wagner 20 (1959). 
been estimated, are living in substandard housing ${ }^{13}$-has constricted the supply of housing available for relocation purposes. ${ }^{14}$ The problem of relocating displacees is further complicated by the fact that a majority of them are non-white families, ${ }^{15}$ to whom many housing sub-markets are closed. Perhaps as a result of these difficulties, renewal communities' record on relocation thus far is not entirely satisfactory. Between 1949 and 1961, almost 9,000 families (seven per cent of the total) were relocated in substandard housing, ${ }^{16}$ while another 17,500 families (fourteen per cent) had moved to unknown locations. ${ }^{17}$ The fact that more than twenty per cent of those displaced are not known to be adequately relocated has prompted both commentators and renewal site families to express dissatisfaction with present relocation efforts. ${ }^{18}$ Indeed, some of those faced with displacement and relocation have turned to the courts in an effort to insure their proper relocation. This Note is concerned with the availability and scope of judicial review of such complainants' grievances.

In Johnson $v$. Redevelopment Agency, ${ }^{19}$ site families brought a class action to enjoin the award of Title I assistance to a renewal project on the ground that the relocation plan was inadequate. They alleged that a housing shortage existed, that the shortage would be aggravated by the renewal program, and

13. President John F. Kennedy, State of the Union Message, Jan. 30, 1961. 1 U.S. Code Cong. \& Ad. News 25, 29 (1961).

14. A shortage of housing is recognized as a principal cause of blight. When supply and demand are balanced in the housing market, the dwelling needs of low and middleincome families are met by a process of "filtering": older housing is released for their use as higher income families move into new units. When this filtering process is blocked by a housing shortage, families at the lower end of the economic scale are left to compete for, and crowd into, whatever housing is available to them. See Johnstone, supra note 5, at 350; Wurster, supra note 12, at 230, 235.

15. Of 86,000 displaced families for whom color was reported, 57,000 were non-white. HHFA, Rezocation Data 8. Present patterns of relocation planning have been criticized for promoting increased segregation, rather than producing integrated communities. Cons. Advisory Conm. to the United States Comm'n on Civir Rights, Report on Conn.: Family Relocation under Urban Renewal 14, 33-39 (1963); New Haven Register, Sept. 28, 1963, p. 1, col. 6.

16. HHFA, Relocation Data 8 (table opposite).

17. Ibid.

18. See, e.g., Creighton, The Scope of Housing Renewal, $22 \mathrm{~J}$. AM. INstrTute of PlanNers 30, 31 (1956); Gans, The Human Implications of Current Redevelopment and Relocation Planning, 25 J. AMr. Institute of Peanners 15 (1961); Grigsby, Houtsing and Shum Clearance: Elusive Gaals, in The Annals of the American Academy of Political and Soctal ScIence 107 (March 1964); Johnstone, supra note 5, at 352; Meltzer, Relocation of Faniilies Displaced in Urban Redevelopment: Expericncc in Chicago, in WoodBury, op. cit. supra note 4, at 409-13; Thabit, Renewal-A Planning Challenge, $26 \mathrm{~J}$. Am. Institute of Planners 84, 85-86 (1960). See also Cogen, The Workable Program for Urban Renewal, 80-81, 144 (1958) (unpublished thesis in Yale Law Library).

19. 317 F.2d 872 (9th Cir. 1963), affirming No. 40834, N.D. Cal., August 29, 1962, cert. denied, 375 U.S. 915 (1963). Defendants included not only the local renewal agency, but the Oakland City government, the Housing Administrator, and other HHFA officials. 
that the Local Public Agency (LPA) ${ }^{20}$ would not be able to fulfill its obligation to relocate site families (especially the eighty per cent that were nonwhite). ${ }^{21}$ Thus, they claimed, the Housing Administrator had wrongfully approved the plan and made an improper award of federal monies. The trial court granted summary judgment for defendants, holding that plaintiffs had failed to show any facts that would prove the relocation plan to be inadequate.22 The Ninth Circuit affirmed, but on different grounds, holding that plaintiffs had no standing to sue. ${ }^{23}$ Two lines of reasoning were intertwined in the court's opinion. First, the court implied, alternative and unpursued remedies available through the Housing Administrator-a depositary of expertise necessary to sensible decision-making in a complex situation-foreclosed any jurisdiction over relocation on the part of courts in those cases where relief was not first sought in the administrative process. ${ }^{24}$ The thought here was not that plaintiffs might not be entitled to relief, but that they had asked the wrong forum to grant it. Second, the court suggested that the plaintiffs did not have a cognizable interest in relocation under the statutea conclusion which would seem to negate the possibility of judicial review at any time. The court supported this position by arguing that section 105 (c) governed the terms of Title I assistance contracts and imposed upon the LPA an obligation to make a showing of the feasibility of relocation before the contract could be consummated. The court then reasoned that enforcement of this contractual condition was delegated solely to the Administrator and that plaintiffs, who sought relief as third-party beneficiaries of the contract, ${ }^{25}$ had no standing to seek enforcement of the relocation provision. ${ }^{20}$

20. A local public agency is defined as "any State, county, municipality, or other governmental entity or public body" authorized to undertake urban renewal projects. 63 Stat. 421 (1949), 42 U.S.C. \$ 1460 (h) (1958).

21. The Johnson plaintiffs represented an estimated 1660 site residents; of these, 1335 were non-white. See Appendix D to the answer of the defendant redevelopment agency (Form H-6122, as submitted to the HHFA in conjunction with the Acorn Project Relocation Plan), at 1.

22. Johnson v. Redevelopment Agency, No. 40834, N.D. Cal., August 29, 1962.

23. 317 F.2d 872, 875 (1963).

24. 317 F.2d at 874-75. The court argued that its denial of standing did not leave plaintiffs remediless, because they had the opportunity to contest the plan at a local hearing (see notes 43-48 infra and accompanying text), and could present grievances to the Housing Administrator. Moreover, in this case, plaintiffs could have challenged the relocation plan in the state courts within 60 days after its adoption. Cal. Healtr \& SAFETY CODE, § 33530 (1955).

25. The considerations determinative of one's status as a third-party beneficiary seem the same as the considerations determinative of standing. The inquiry in both cases is whether the complainant's interest is sufficient to warrant judicial intervention on his behalf. Cumpare 3 Davis, Administratrve Law ch. 22 (1958) (standing), with 4 CoRBIN, CoNTRACTS $\S \S 772-855$ (1951) (third-party beneficiaries).

26. 317 F.2d 872, 874 (1963). The court suggested that Congress did not intend to create a right of action in those not a party to the federal assistance contract. It cited Hunter v. City of New York, 121 N.Y.S.2d 841 (Sup. Ct. 1953), a case in which a New York trial court denied standing to site families on the ground that they had no "vested 
Insofar as it suggests that renewal site families have no "rights" sufficient to merit standing to protest acts of the Administrator in enforcing section 105(c), the Ninth Circuit's decision, in effect, forecloses all judicial review of the plaintiffs' claim, ${ }^{27}$ and seems an unwarranted refusal to afford judicial protection to the families" "interests" in relocation. Were relocation in standard housing not required, renewal might inflict substantial harm, economic and emotional, on displacees. ${ }^{28}$ While, by its terms, section 105 (c) only controls the provisions of the federal aid contract, ${ }^{29}$ the point of such control is to insure the proper treatment of site families. The statute thus appears to recognize the interests of, and to offer some protection to, these people. ${ }^{30}$ When a party seeks judicial relief from an injury inflicted by administrative action upon an interest recognized by statute, standing and review traditionally obtain ;1 indeed, it has been said that the cases establish a presumption of a right" to relocation, since Congress might repeal $\S 105(c)$ at any time. The Supreme Court has refused to find the "vested right" theory determinative in a case involving similar interests. Parker v. Fleming, 329 U.S. 531 (1947). In Parker, plaintiff tenants sought judicial review of the actions of the Price Administrator in granting eviction certificates to their landlord. Even if the "vested right" theory is accepted, it would seem that the interests of site families in relocation should be determined by the statutory provisions in effect at the time of the contract governing the particular project.

The Hunter court ruled alternatively that it had no power to review the actions of the Housing Administrator. Subsequent New York decisions have emphasized this jurisdictional point. Spadanuta v. Rockville Centre, 224 N.Y.S.2d 963 (Sup. Ct. 1962).

27. See Jaffe, The Right to Judicial Review I, 71 HARV. L. REv. 401, 421 (1958).

28. Displaced families would be forced to bear the entire cost of locating substitute housing and might be faced with the prospect of higher rent if the result of the renewal activity is increased demand for housing. See note 14 supra. To the extent that renewal destroys neighborhood living patterns, its impact on the emotional lives of displacees is incalculable. See Gans, supra note 18; Fried \& Gleicher, Some Sources of Residential Satisfaction in an Urban Slum, $27 \mathrm{~J}$. Ax. Instrtute of Planners 305 (1961). For an analysis of the type of people who live in slums and the ways in which their social patterns differ from the rest of the urban population, see Seeley, The Slum: Its Nature, Use, and Users, $25 \mathrm{~J}$. ANr. INSTITUTE of PlanNers 7 (1959).

29. See note 5 supra.

30. Of course, relocation alone cannot compensate for many of the hardships inflicted on displaced families by renewal. See note 28 supra. But the notion of aiding site families in a tangible manner does indicate an awareness of their burden and an atterpt to alleviate it. See the report of the Senate Committee, supra note 9. In addition to the requirements of $\$ 105(\mathrm{c})$, the federal statute permits the LPA to reimburse displaced families up to $\$ 200$ for their moving expenses and direct losses of property. The expense of this program is borne by the federal government. 70 Stat. 1100 (1956), as amended, 42 U.S.C. $\$ 1456(\mathrm{f})$ (Supp. IV, 1962).

31. The leading case is The Chicago Junction Case, 264 U.S. 258 (1924). There, the ICC had permitted a single railroad to acquire control of a previously independent terminal railroad. Competing railroads, who claimed that this action was not in the public interest because it took from them equal access to the Chicago market, were permitted standing to contest the ICC's order. The court, speaking through Mr. Justice Brandeis, declared:

[This] is injury inflicted by denying to the plaintiffs equality of treatment. To such treatment carriers are, under the Interstate Commerce Act, as fully entitled as any shipper .... By reason of this legislation, the plaintiffs, being competitors 
right to judicial review in persons whose interests are "acutely and immediately affected" by an administrative action. ${ }^{32}$ The Second Circuit has followed this doctrine in Gart $v$. Cole, ${ }^{33}$ where the court granted site families standing to contest the procedures adopted by the Administrator to enforce the relocation requirement. ${ }^{34} \mathrm{~A}$ decision granting standing would conform not only to precedent but also to the counsel of the Administrative Procedure Act; ${ }^{35}$ section 10 of the APA, which apparently codifies the presumption in favor of judicial review, ${ }^{36}$ provides for judicial intervention at the instance

of the New York Central and users of the terminal railroads heretofore neutral, have a special interest in the proposal to transfer the control to that company.

Id. at 267.

See the discussion in Jaffe, Standing to Secure Judicial Reviezw: Private Actions, 75 Harv. L. REv. 255, 262-69 (1961). See also Mr. Justice Frankfurter concurring in Joint Anti-Fascist Refugee Committee v. McGrath, 341 U.S. 123, 152 (1951).

In the absence of an applicable statutory review procedure, a court's jurisdiction is based on its general equity powers. Leedom v. Kyne, 358 U.S. 184, 187 (1958) ; Harmon v. Brucker, 355 U.S. 579, 581 (1958) ; Stark v. Wickard, 321 U.S. 288, 307 (1944); American School of Magnetic Healing v. McAnnulty, 187 U.S. 94, 107 (1902).

To the extent that present relocation methods result in increased racial segregation among displaced families (see note 15 stipra), they would seem to have standing to protect their interest in equal protection as recognized by the Fourteenth Amendment.

32. Jaffe, supra note 27, at 420 (1958). See also id. at 420-37; Davis, Unreviewable Administrative Action, 15 F.R.D. 411, 426 (1954); 4 Davis, Adurnistrative LAW $\$ \S 28.05-21$ (1958); Kramer, The Place and Function of Judicial Review in the Administrative Process, 28 FordeAMr L. Rev. 1, 12 (1959). See note 31 supra. These commentators agree that only an express statutory intent to exclude judicial review should justify a court's refusal to intervene, and the Supreme Court seems to have recognized this principle. See United States v. ICC, 337 U.S. 426, 433-35 (1949). Compare Leedom v. Kyne, 358 U.S. 184 (1958) and Stark v. Wickard, 321 U.S. 288 (1944), with Switchmen's Union v. National Mediation Bd., 320 U.S. 297 (1943) (4-3 decision).

33. 263 F.2d 244 (2d Cir. 1959), affirming 166 F. Supp. 129 (S.D.N.Y. 1958), cert. dcnicd, 359 U.S. 978 (1959).

34. 263 F.2d at 250-51. Plaintiffs in Gart argued that the Administrator had a duty to grant them an oral hearing on the feasibility of a relocation plan. The court held that there was no such requirement. Plaintiffs also alleged that the Administrator had delegated his responsibility to review relocation planning. See note 6 supra. But the court held that they had failed to present any proof of such misconduct.

35. 60 Stat. 237 (1946), as amended, 5 U.S.C. $\$ \$ 1001-11$ (1958).

36. Section 10 provides for judicial review of administrative action "except so far as (1) statutes preclude judicial review or (2) agency action is by law committed to agency discretion." 60 Stat. 243 (1946), 5 U.S.C. $\$ 1009$ (1958). The legislative history indicates a congressional desire that, except in those rare cases where Congress has clearly excluded review, judicial review of all administrative action be available; discretion, it was felt, goes to the question of relief, not of review. H.R. REP. No. 1980, 79th Cong., 2d Sess. 41 (1946). Professor Jaffe believes that the APA has had little effect on the basic right to review; he sees $\S 10$ as a codification of the case-law presumption. See Jaffe, The Right to Judicial Review II, 71 HARv. L. Rev. 769, 790 (1958). Even so, $\S 10$ has had an impact on the Court's approach to-and sometimes on its decision in-cases raising the question of review. Compare Brownell v. Tom We Shung, 352 U.S. 180, 185 (1956), with Heikkila v. Barber, 345 U.S. 229 (1953). 
of "any person adversely affected or aggrieved ... within the meaning of any relevant statute." 37 Given the apparent purpose of section 105(c), renewal displacees seem well within this definition. Moreover, a denial of standing to site families silences the principal voice which might serve to check improper administration of section 105 (c).$^{38}$ Finally, an absolute refusal by the court to intervene in the administration of section 105 (c) at the instance of site families seems an abdication of the court's traditional institutional responsibility to insure that administrative action is confined to the bounds of agency discretion and authority. ${ }^{39}$ If the court in Johnson meant to deny standing and preclude review in this absolute sense, then its decision seems wrong. But the court may not have intended such a harsh result; its refusal to entertain the plaintiffs' claim might have resulted from a failure to pursue what the court felt was an available administrative remedy. ${ }^{40}$ If this limited ground was the basis for the decision, however, the court's use of the standing doctrine produces needless confusion; the court might better have invoked doctrines of finality, exhaustion, or ripeness to support its holding. ${ }^{41}$

Assuming that the Johnson court meant only to deny standing in this limited sense, the wisdom of its decision would seem to depend upon the

37. 60 Stat. 243 (1946), 5 U.S.C. $\$ 1009$ (a) (1958). A wide variety of interests have been granted judicial recognition under a similar provision of the Communications Act. 48 Stat. 1093 (1934), as amended, 47 U.S.C. \$ 402(b) (1958). E.g., FCC v. Sanders Bros. Radio Station, 309 U.S. 470 (1940) (existing station granted standing to allege violations of law in agency's award of license for second station in same locality) ; Columbia Broadcasting System v. United States, 316 U.S. 407 (1942) (network affected by regulations directed to broadcasting stations allowed standing to contest validity of regulations) ; Philco Corp. v. FCC, 257 F.2d 656 (D.C. Cir. 1958) (competitor of licensee's parent company allowed to protest renewal of license on ground that award was not in public interest. Complainant's sole injury resulted from alleged unfair advertising advantages gained by the parent). See also Parker v. Fleming, 329 U.S. 531 (1947), where plaintiff tenants were found to be "subject to" an eviction order granted to their landlord by the Price Administrator, and thus entitled to judicial review under the relevant statutory provision.

38. Standing is sometimes justified on the ground that the complaining party is the only person likely to protect the "public interest." FCC v. Sanders Bros. Radio Station, supra note 37; Scripps-Howard Radio, Inc. v. FCC, 316 U.S. 4, 14 (1942) ; Parker v. Fleming, supra note 37; Associated Industries v. Ickes, 134 F.2d 694, 704 (2d Cir. 1943) (wherein Judge Frank characterized the plaintiffs as "private attorney generals"). This theory would seem the explanation of Housing \& Redevelopment Auth. v. Minneapolis Metropolitan Co., 259 Minn. 1, 104 N.W.2d 864 (1960), in which the court granted standing to a corporate owner of site property to contest the feasibility of relocation.

39. Cf. Jaffe, supra note 27, at 401-10; Kramer, supra note 32, at 6 .

40. See note 24 supra and accompanying text.

41. Each of these doctrines relates to the timing of judicial review. In many respects, they seem interchangeable. Thus, it might be argued that because a party had failed to exhaust his administrative remedies, the administrative action could not be regarded as final, since the agency might change its course in response to a properly directed complaint. Similarly, it might be said that an agency action which could not be considered as final was not ripe for review, since injury to the complainant was not certain to vecur. For a general discussion of these three doctrines, and the even more puzzling doctrine of primary jurisdiction, see Kramer, supra note 32, at 36-44. 
availability of an administrative proceeding in which the interests of site families can be meaningfully protected. ${ }^{42}$ The Housing Act ${ }^{43}$ and many state enabling acts ${ }^{44}$ require the renewal community to conduct a public hearing prior to the implementation of the renewal plan, and HHFA regulations permit the award of federal aid only after such a hearing has been held. ${ }^{45}$ Since renewal planning is the responsibility of the participating communities, ${ }^{46}$ these local hearings provide an important forum for the site family to test the LPA's relocation proposals : if the local hearing board (which may be the LPA, the community governing body, or other local authority) ${ }^{47}$ is persuaded that additional provision for site families is necessary or desirable, the relocation plan can be revised before it is submitted to the HHFA for the Administrator's review and approval. But, the possibility that the local hearing board may tend to accept uncritically the LPA's already formulated relocation plan suggests that the community public hearing may offer only limited protection to renewal displacees. ${ }^{48}$ The availability of a local hearing, then, does not seem sufficient to justify the court's remitting the Johnson plaintiffs to the administrative process.

After the local hearing and endorsement by the community governing body, ${ }^{40}$ the renewal plan-along with detailed information documenting the community's need for Title I assistance and its ability to perform the renewal task ${ }^{50}$-is submitted by the LPA to the HFFA for approval and award of federal monies. ${ }^{51}$ On the basis of relocation data submitted by the LPA, ${ }^{52}$ the

42. There would seem no reason for the court to remit the plaintiffs to an inadequate or unavailable administrative remedy. Cf. United States Alkali Export Ass'n v. United States, 325 U.S. 196 (1945) ; Smith v. Illinois Bell Tel. Co., 270 U.S. 587 (1926).

43. 63 Stat. 417 (1949), 42 U.S.C. $\$ 1455$ (d) (1958).

44. See, e.g., Cal. Health \& Safety Code $\$ \$ 33530-35$ (1955); Conn. Gen. Stat. \$ 8-127 (1958); Mass. Ann. Laws ch. 121, \$ 26KK (Supp. 1963) ; Mo. Stat. Ann. $\$ 99.430(9)$ (1952); Pa. Stat. ANN. tit. 35, \$ 1710(g) (Supp. 1963).

45. HHFA, URM ch. 4-3, at 1 .

46. See generally, the Congressional Declaration of National Housing Policy in the Housing Act of 1949. 63 Stat. 413 (1949), 42 U.S.C. $\$ 1441$ (1958) ; HHFA, URM pt. 1.

47. HHFA, URM ch. 4-3, at 1 .

48. For an excellent critique of the local public hearing in a renewal context, see Sullivan, Administrative Procedure and the Advocatory Process in Urban Redevelopment, 45 CALIF. L. REv. 134, 143-49 (1957). Not only are LPA presentations supported by data, but they are often designed with an eye to selling the renewal program to the community's governing body, its citizens, and the HHFA. See generally id. at 145-47. See also Note, 69 Y ALE L.J. 321,328 (1959).

49. After the local public hearing, the renewal plan must be approved by the community governing body, with findings that: 1) federal aid is necessary to carry out the project; 2) the plan provides maximum opportunity for private enterprise to participate in the renewal effort; 3 ) the plan conforms to a general plan for the community; 4) the plan gives consideration to the need for parks and recreation facilities. 63 Stat. 417 (1949), as amended, 42 U.S.C. \$ 1455(a) (Supp. IV, 1962).

50. An outline of the submission requirements for Title $I$ assistance is found in HHFA, URM pt. 10.

51. The procedures of submission are summarized in HHFA, URM pt. 4.

52. Kelocation submission requirements are detailed in HFFA, URM pt. 16. 
Administrator determines whether the community's relocation planning meets the statutory standard: section 105 (c) requires that "there are or are being provided ... decent, safe, and sanitary dwellings equal in number to the number of and available to such displaced families." interpreted this provision as requiring that the LPA demonstrate its ability to make available standard housing-usually defined by planners as dwellings which meet local building and housing code standards ${ }^{4}$ - to all displaced families. ${ }^{55}$ Regulations promulgated under this interpretation require the community to show that it will provide a professional staff to aid site families in the effort to locate housing ${ }^{56}$ and that community housing conditions are such that the relocation staff will be able to locate decent dwellings for all families. In support of this latter conclusion, the LPA is required to estimate the vacancies that will occur during the displacement period in public housing, in sales housing, and in private rental housing, and to indicate what portion of those vacancies will be available to non-white families. ${ }^{57}$ The LPA must simultaneously survey a sample of the site families to determine their housing needs. ${ }^{58}$ The anticipated needs of all displacees are then compared with the estimated supply of housing to provide data from which the Administrator can form a judgment as to the LPA's ability to effectuate proper relocation. ${ }^{59}$ The minimum showing seemingly permitted by the HHFA regulations is a demonstration that anticipated vacancies in decent housing equal the number of families to be displaced and a statement that a relocation staff will exist to place the site families in those vacancies. ${ }^{60}$ But such a showing should not

53. 63 Stat. 417 (1949), as amended, 42 U.S.C. $\$ 1455$ (c) (1958). The full text of this provision is set forth at note 6 supra.

54. Hexidahl, URBAN ReNEwal 201 (1959). Adequate codes are required as part of the renewal community's Workable Program. HHFA, How Localrtres CAN Deverop a Workable Program for Urban Renewal 5 (1956). In 1954, the Workable Program was made a statutory prerequisite for federal assistance for urban renewal, public housing, and some forms of FHA mortgage insurance. 68 Stat. 623 (1954), as amended, 42 U.S.C. $\$ 1451$ (c) (Supp. IV, 1962). Its purpose is to evidence the community's ability and willingness to achieve renewal goals. The HHFA has prescribed seven elements necessary to a Workable Program. See, e.g., HHFA, The Workable Program - What Ir Is 4-5 (1957). See generally Cogen, The Workable Program for Urban Renewal (1958) (unpublished thesis in Yale Law Library).

It has been suggested that this definition puts undue emphasis upon physical standards and fails to recognize that low income families are often more concerned with neighborhood social patterns. Gans, supra note 18 , at 20 . See generally Fried \& Gleicher, supra note 28; Seeley, supra note 28.

55. See note 8 supra and accompanying text.

56. HHFA, URM \$ 16-2-1, at 1 .

57. This information is submitted on HFFA Form $\mathrm{H}-6122$, which is reproduced as Exhibit A to HHFA, URM $\S 16-2-2$. Estimated housing resources are reported according to size and price on pp. 4-5 of the form, and a summary of the LPA's estimates is reported on p. 1.

58. Id. at 2-3.

59. Id. at 4-5.

60. "The estimates of housing resources in each size and housing cost range must, as a minimum, equal the estimated rehousing needs of the families." HHFA, FIEID SERnCE MaNUAI \& 16-1-3. 
persuade the Administrator that the statutory standard can be met; the shortage of adequate dwellings and the resulting competition in the housing market will make it unlikely that all anticipated vacancies can be secured for site families. ${ }^{01}$ At the other extreme, a proposal to provide a quantity of new housing for relocation purposes equal to the number of displaced families should merit the Administrator's approval. If a relocation plan which falls between these extremes is proposed, the task of the Administrator is to determine whether the relocation staff can reasonably be expected to secure adequate rehousing for all site families, balancing their needs against the anticipated housing resources.

The problem which may arise in connection with the Administrator's review of relocation planning, and which is presented by the Ninth Circuit's opinion in Johnson, is whether site families must be afforded opportunity to present the Administrator with opposing views as to the feasibility of relocation. The interests of site families in relocation which justify standing in the judicial process ${ }^{62}$ would seem to warrant their intervention at this stage, and the Ninth Circuit was evidently concerned that the Johnson plaintiffs had failed to lay their grievances before the Administrator. ${ }^{63}$ Yet although the Administrator has permitted site families to submit documentary evidence in opposition to community relocation planning on at least one previous occasion, ${ }^{64}$ the HHFA has no announced procedure by which such grievances may be presented. ${ }^{65}$ The Administrator's review of relocation planning is apparently not subject to the notice and participation requirements of section 4 of the Administrative Procedure Act, since the proceeding relates to "public .. . loans, grants, . . . [and] contracts."66 Nor does the Housing Act pre-

61. See note 14 supra and accompanying text. See also note 77 infra and accompanying text. Unless one is to argue for compulsory relocation into LPA selected quarters, there must also be some allowance for family choice among available dwelling units. Some of the problems which result from an arbitrary classification of family needs, and a failure to allow for the selection factor are suggested in ConN. ADvisory Consr. ro the United States Coarm'n on Civin Rights, Report on Conn.: Fanmly Relocation UNDER URBAN RENEWAL 24 (1963).

62. See notes $27-38$ supra and accompanying text. Standing to appeal may not necessarily imply a right to an administrative hearing. There may be situations in which intervention at the administrative level would be unwarranted. See Jaffe, supra note 31, at 283-84.

63. See note 24 supra and accompanying text.

64. The plaintiff site families in Gart v. Cole, supra note 33, were permitted to submit evidence. They claimed that the Administrator was also required to grant them an oral hearing. The court denied this claim, holding that the Housing Act required nothing more than the permitted protest. 263 F.2d at 250-51.

65. No provision for site family protests is made in the URM, and an interview with the Regional Counsel of the HHFA in New York revealed that the agency has no formal grievance procedure. The agency is, however, wont to consider challenges to community planning when submitted.

66. Section 4 of the APA provides for notice of proposed agency action and for a protest procedure in all cases of rule-making "except to the extent that there is involved ... (2) any matter relating to agency management or personnel or to public property, 
scribe any method by which the Administrator is to enforce the relocation requirement. But while the method of enforcing section 105 (c) thus seems to be a matter of administrative discretion, once the Administrator has elected to base his determination primarily on data submitted by the LPA-rather than on independent HHFA investigations ${ }^{67}$ or on the record made at the local public hearing ${ }^{68}$-it would seem that he must consider proffered protests to that data. Otherwise, his determination can be based only on those facts which the LPA has chosen to submit and will be susceptible to attack as arbitrary or as an abuse of discretion. ${ }^{69}$ However, since the Administrator's review of LPA relocation planning is based on written submissions, his duty to hear site families would seem discharged by a consideration of their written protests, ${ }^{70}$ and the Second Circuit has held that he need not grant an oral hearing to protesting displacees. ${ }^{71}$ In view of the predominantly statistical data required by the Administrator, demeanor evidence would seem of rela-

loans, grants, benefits, or contracts." 60 Stat. 238 (1946), 5 U.S.C. $\$ 1003$ (1958). The Administrator's approval of community relocation planning otherwise meets the APA's definition of a rule. See 60 Stat. 237 (1946), 5 U.S.C. $\$ 1001$ (c) (1958).

67. Renewal planning under Title $I$ is a matter of community responsibility. See note 46 supra. In keeping with this policy, the Administrator does not conduct independent surveys of local housing needs and resources or dictate the content of local relocation planning. Howard, The Role of the Federal Government in Urban Land Use Planning, 29 FordHAM L. Rev. 657 (1961). The HHFA does, however, oversee the execution of renewal projects in a general way; a site representative is designated for each approved project. Among the responsibilities of the site representative is spot inspection of the LPA relocation effort; he is to report non-compliances to the LPA and to the Regional office of the HHFA. HHFA, Polictes and Procedures for Urban Renewal. Operations - Field Service ch. 8-2.

68. Administrative regulations presently require only the submission of a certified copy of excerpts from the minutes, showing a) the date, time, and place of the hearing; b) that the hearing was held and opportunity accorded to all to present their views; $c$ ) the official action, if any, taken by the hearing board. HHFA, URM ch. $4-3$, at 3 . But even if a transcript of the local hearing were submitted to the Administrator, it might not form an adequate basis for his review since the LPA might modify its relocation proposals between the date of the hearing and submission to the HHFA. Only in some cases will such a modification require a second public hearing. Id. at 1 .

69. Cf. The Chicago Junction Case, 264 U.S. 258 (1924), where the court held that parties within the ambit of a relevant statute were entitled to equal treatment by the agency. See note 31 supra.

70. Since the Administrator's duty to hear arises because he considers LPA submissions, that duty would seem discharged when he affords equal treatment to other complainants. See note 69 supra and accompanying text. Rulemaking under the APA requires that "the agency shall afford interested persons an opportunity to participate in the rule-making through submission of written data, views, or arguments with or without opportunity to present the same orally in any manner." 60 Stat. 239 (1946), as amended, 5 U.S.C. $\S 1003$ (b) (1958). Although this provision of the APA does not apply to the Administrator's review of relocation planning (see note 66 supra and accompanying text), the general acceptability of a written procedure in the administrative process suggests its suitability here.

71. Gart v. Cole, 263 F.2d 244 (2d Cir. 1959), affirming 166 F. Supp. 129 (S.D.N.Y. 1958), cert. denied, 359 U.S. 978 (1959). See notes 33-34 supra. 
tively little importance, and a written protest procedure appears to provide the Administrator with an adequate basis for his decision.

In contesting the feasibility of relocation before the Housing Administrator, a site family will have to counter the LPA's data-supported plan with evidence showing that conditions in the housing market will not permit the proper rehousing of all displacees. Two types of evidence might be submitted. The family might attempt to show that the LPA's factual predictions are erroneous. In support of such a claim, alternative studies of displacees' housing needs and of anticipated vacancies, conforming to the HHFA submission requirements, might be submitted. ${ }^{72}$ Alternatively, the family might seek to go beyond the basic submission requirements and to show that conditions not otherwise made known to the Administrator will prevent adequate relocation. Since the HHFA does not require an LPA to analyze competing demands from other housing consumers for the anticipated vacancies in decent housing, ${ }^{73}$ the protesting site family may try to show that this competition will be so severe that the relocation staff, even with its expertise, cannot be expected to secure the dwellings necessary for relocation purposes. ${ }^{74}$ In addition, the intervening family may be able to show that this competition for available dwellings will be aggravated by the community's renewal activities, since many projects destroy more housing than they create. ${ }^{75}$ In such a "squeeze" situation, com-

72. In view of the predictive nature of the data involved in relocation planning, it would seem that quite different conclusions might obtain from two studies of the same raw material; the conclusion reached would depend upon the investigator's sampling technique and upon the method of forecasting. The disparate results reached in real estate appraisals seem illustrative.

73. The HHFA does require the LPA to consider competing demands for standard housing by families who will be displaced through other governmental activities. HHFA, URM $\S 16-2-2$, at 1 . But express consideration of competing demands from normal housing consumers is not required. Presumably, however, the Administrator, and other experts within the HHFA, are able to allow for such demand in their review of community relocation proposals. See, c.g., HHFA, Field Service Manual $\$ 16-1-3$, at 2.

74. The effects of competition in the lower-end of the housing market are discussed at note 14 supra. Its effects are particularly pronounced in public housing, for which demand is often greater than supply. Johnstone, supra note 5, at 335. Renewal displacees have a statutory preference for admission to federally aided public housing. 63 Stat. 423 (1949), as amended, 42 U.S.C. $\$ 1410$ (g) (Supp. IV 1962). Accelerated competition for available public housing units may thus result in public housing serving only as relocation housing. Yet, public housing is not intended to serve only as relocation housing, as is demonstrated by the failure of a 1954 amendment restricting new public housing to renewal communities needing such units for relocation purposes. 68 Stat. 631 (1954). This provision was repealed in 1955, 69 Stat. 638 (1955), as amended, 42 U.S.C. $\$ 1451$ (Supp. IV 1962), following a House Committee report that it unduly restricted the public housing program. H.R. REP. No. 913, 84th Cong., 1st Sess. 18 (1955).

75. Renewal localities tend to emphasize spectacular central city redevelopment projects; redevelopment sites, which often formerly were high density slums, are commonly rebuilt with luxury apartments or commercial and industrial facilities. Johnstone, The Federal Urban Renewal Program, 25 U. CHI. L. Rev. 301, 321 (1958); Cogen, The Workable Program for Urban Renewal, 144 (1958) (unpublished thesis in Yale Law Library). Sce also Morris, Title I Relocation, 14 RECORD of N.Y.C.B.A. 533, 539 (1959). 
petition for available housing is heightened, ${ }^{76}$ and the supply of decent housing may be decreased, since increased pressure on the housing market may cause some decent housing to deteriorate to substandard levels. ${ }^{77}$ Faced with such claims, the Administrator's task is to resolve the competing factual predictions and to determine whether the LPA can be expected to meet the relocation requirement of section $105(\mathrm{c})$, as that standard has been interpreted. The Administrator, with his presumed expert knowledge and experience in the field of relocation, would seem well equipped to perform this task. ${ }^{78}$ Moreover, his power to withhold federal monies or to condition the award of federal assistance if necessary to the enforcement of section $105(\mathrm{c})^{\mathbf{7 9}}$ suggests that he is able to afford meaningful protection to the site families' interests in relocation. The apparent availability and efficacy of this procedure, coupled with the congressional delegation of responsibility for enforcing section 105 (c) to the Housing Administrator, ${ }^{80}$ suggests that the court in Johnson was right in refusing to take jurisdiction of plaintiffs' claim when they had failed to pursue their administrative remedy. Judicial intervention in Johnson would have by-passed the Administrator's hearing, thereby minimizing the effectiveness of his role in future cases, as well as depriving the court of his experienced consideration of the factual issues. Moreover, had the court intervened, it would have been required to conduct an independent fact-finding proceeding,

Such redevelopment programs are intended to restore the community's tax base and to bring urban land uses into conformity with modern planning concepts. Sullivan, supra note 48 , at 136-38. Such programs apparently meet the public purpose requirement. $C f$. Berman v. Parker, 348 U.S. 26, 33 (1954) (dictum).

76. See generally Thabit, Renewal $-A$ Planing Challenge, $26 \mathrm{~J}$. Ax. Instrrute of Planners 84, 86 (1960).

77. Increased demand for housing is felt largely at the bottom of the housing market. See note 14 supra. While the Workable Program requires of a community adequate codes and the ability to enforce them (see note 54 supra), a community with a decreasing housing supply is faced with a difficult, and perhaps impossible, choice between overcrowding and code enforcement: conscientious enforcement in such a squeeze situation can only result in additional displacement, thus further aggravating the squeeze. Perhaps as a result of this vicious circle, the renewal community often does not even have a staff capable of enforcing its codes, Rhyne, The Workable Program - A Challenge for Community" Improvement, $25 \mathrm{LAW}$ \& ConтEMr. Рвов. 685, 696 (1960), even though code enforcement is recognized as one of the cheapest and most effective techniques for preventing urban decay. See, e.g., Leberman, Taylor \& Wellwood, Code Enforcement - A Ncglected Tool in Planning and Urban Renewal, 1961 Planning 14; Reath, Housing Law Enforcement: Its Role in Urban Renewal, 23 SHINGLE 86 (1960).

78. The Administrator is able to bring not only his own experience but also that of staff members withir the HHFA to a consideration of the competing views as to the feasibility of relocation. At the present time, he relies strongly on staff reports, at least in situations where the LPA submission is not contested. See HHFA, FIeld Service MANUAL ch. 16-1.

79. The Administrator's powers are set forth in detail in $\S 106(\mathrm{c})$ of the Housing Act, 63 Stat. 417 (1949), as amended, 42 U.S.C. \& 1456(c) (Supp. IV 1962).

80. 63 Stat. 414 (1949), as amended, 42 U.S.C. $\$ 1451$ (c) (Supp. IV 1962). See note 7 supra. 
rather than being able to base its review on the record made before the Administrator.

It would seem, then, that the Johnson decision should be read as a limitation on site families' ability to obtain judicial review only when they have neglected to seek relief in the administrative process. But if the decision is so limited, it does not bear on the availability or scope of judicial review once the Administrator's determination becomes final. Both case law ${ }^{81}$ and the Administrative Procedure Act ${ }^{82}$ suggest that review at this stage should be available, and judicial supervision seems necessary to insure that the Administrator properly protects the interests of site families. ${ }^{83}$ Moreover, the issues involved in relocation planning do not seem beyond the abilities of a court. ${ }^{84}$ There is thus every reason to afford protesting families judicial review of the Administrator's decision, the scope of such review depending upon whether the parties contest the Administrator's factual determinations or his interpretation and application of section $105(\mathrm{c})$. The Administrator's presumed expertness in resolving issues of fact, and the existence of a procedure which is capable of bringing all relevant evidence to his attention, suggest that a court should refrain from substituting its own judgment on factual questions. The effect of such substitution would be to vitiate substantially the administrative process by reducing the Administrator to a mere collator of facts. Judicial restraint is also suggested by the fact that Congress has delegated to the Administrator primary responsibility for enforcing the relocation provision. ${ }^{85}$ Review of administrative factual determinations is customarily guided by the substantial evidence rule, ${ }^{86}$ and this rule would seem appropriate in section 105 (c) cases. Under this doctrine, an agency finding can be upset by a court only if it is unsupported by substantial evidence on the whole record. ${ }^{87}$

S1. See notes $31-34$ and note 38 supra.

82. See notes 35-37 supra.

S3. See note 39 sutpra.

84. The courts evaluate similar predictions of housing market behavior in eminent domain compensation suits, and much more complex and diffuse issues of market behavior are presented in the usual anti-trust proceeding. Moreover, given the somewhat limited scope of review advocated in this Note (see notes 86-88 infra and accompanying text), a court need examine the factual data only to determine whether it supports the Administrator's determination.

S5. 63 Stat. 414 (1949), as amended, 42 U.S.C. \$ 1451(c) (Supp. IV 1962).

86. Universal Camera Corp. v. NLRB, 340 U.S. 474 (1951). See 4 Davrs, AdarrnisTRATTVE LAW \$\$ 29.01-.11 (1958); Jaffe, Judicial Review: Question of Fact, 69 Harv. L. REv. 1020, 1021 (1956); Kramer, The Place and Function of Judicial Review in the Adrinistrative Process, 28 FordeAMr L. REv. 1, 76 (1959). The substantial evidence test has been adopted by the Administrative Procedure Act in all cases where an agency hearing is required by statute, except insofar as the agency action is discretionary. 60 Stat. 243 (1946), 5 U.S.C. $\$ 1009$ (1958).

87. Universal Camera Corp. v. NLRB, supra note 86. The APA provides for the court to "review the whole record or such portions thereof as may be cited by any party." 60 Stat. 244 (1956), 5 U.S.C. $\$ 1009$ (e) (1958). Professor Jaffe argues that the courts are gradually adopting the substantial evidence test as the measure of review in all cases except those in which Congress expressly provides another standard. Jaffe, supra note 86. 
Judicial review under this standard would permit the Administrator the flexibility necessary to effective decision-making, while allowing the court to exercise its supervisory function by confining the Administrator's determination to the limits of rationality..$^{88}$

A court reviewing the Administrator's interpretation of section 105 (c) should similarly be guided by an awareness of the Administrator's responsibility to formulate workable policy consistent with a generalized statutory goal; the task of the court would seem to be to insure that the Administrator's interpretation is, in fact, effectuating the statutory purpose..$^{89}$ The purpose of section 105 (c) seems reasonably clear; it requires as a condition to the award of Title $I$ assistance that decent housing exist and be available to all displaced site families. ${ }^{90}$ However, the Administrator's interpretation of the provision - requiring the LPA to show that it will be able to rehouse all displacees satisfactorily ${ }^{91}$-has been criticized as demanding too little to accomplish the statutory purpose. ${ }^{92}$ Two main factors seem to underlie this criticism. First. the Administrator's reliance on the referral technique to place site families in adequate housing has not proved entirely satisfactory : in the past, only about

Professor Davis, however, feels that the courts often abandon the substantial evidence rule in favor of a broader standard which allows them to substitute their own judgment on factual matters. 4 Davis, Administrative LAw $\S 29.07$ (1958).

88. Professor Jaffe suggests that the question on review is whether one can reason from the evidence to the announced determination. Jaffe, supra note 86, at 1022-23.

89. Professor Jaffe has analyzed the scope of review of questions of law in terms of the "clear statutory purpose" test. See Jaffe, Judicial Review: Question of Law, 69 HaRv. L. Rev. 239, 258-62 (1955). Thus, he argues that an agency should be permitted to determine policy so long as that policy coincides with what the court perceives as the clear purpose of the statute. See also Kramer, stpra note 86, at 87. Professor Davis identifies the central factor guiding the scope of review of questions of law to be the relative qualification of court and agency to deal with a given problem. 4 DAvss, ADMinistrative LAw $\S 30.09$ (1958). This test, too, would seem to justify judicial review of the Administrator's interpretation of $\S 105(\mathrm{c})$; the court seems both more qualified and in a better position to determine whether the Administrator's policies effectuate the statutory purpose.

90. The text of $\S 105(c)$ is reproduced at note 6 supra. See also notes 9,30 supra and accompanying text.

91. See note 8 supra and accompanying text.

92. See, e.g., Creighton, The Scope of Housing Renewel, $22 \mathrm{~J}$. Am. INstitute of Planners 30, 31 (1956) ; Grigsby, Housing and Slum Clearance: Elhsive Goals, Tнe Annals of the Amertcan Academy of Poltrical and Soctal Scrence March 1964, at 107; Meltzer, Relocation of Families Displaced in Urban Redevelopment: Expericnce in Chicago, in Woodsurry at 452; Thabit, Renewal - A Plannitrg Challenge, $26 \mathrm{~J}$. Am. Institute of Planners 84 (1960). Others attribute shortcomings in the present program to a lack of emphasis or enforcement of the relocation requirements. Howard, The Role of the Federal Government in Urban Land Use Planning, 29 FoRDEAMr L. Rev. 657 (1961); Leach, The Federal Urban Renewal Program: A Ten-Year Critique, 25 LAw \& Contemp. Prob. 777, 788 (1960); Cogen, The Workable Program for Urban Renewal 144 (1958) (unpublished thesis in Yale Law Library). The low priority of relocation is evidenced by the fact that less than $1 \%$ of renewal monies are spent in this area. Gans, The Human Implications of Current Redevelopment and Relocation Planning, 25 J. Ax. INSTITUTE OF PLANNERS 15, 22 (1959). 
one fourth of site families have availed themselves of referral services provided by LPA's; $;{ }^{93}$ the remaining three fourths have relocated themselves. ${ }^{94}$ Since self-relocating families lack the expertise of the professionals employed by the LPA's referral service, it is reasonable to assume that the housing shortage will have forced some of them to accept substandard accommodations. Although the HHFA requires the LPA to inspect the new housing of those who are self-relocated and to offer referral assistance to those who have established themselves in substandard quarters, ${ }^{95}$ it has been true that, among these people who have rejected assistance when it was first offered, ${ }^{96}$ some have not been inclined to accept help the second time around. ${ }^{97}$ Second, even if the referral service succeeds in placing most displaced families in standard dwellings, the pressure to accommodate renewal displacees and regular housing consumers in a market of limited supply makes difficult the maintenance of proper living conditions. Consequently, relocation housing which meets local code requirements on the date of relocation may become overcrowded and substandard as the competition increases. ${ }^{98}$ There thus seems support for the critics' observation that the goal of relocating all displacees in decent, safe, and sanitary housing has not been effectuated under present administrative policies. These critics of the current relocation program suggest that section 105(c) must be interpreted as requiring the creation of a community housing environment in which all displaced families will be able to find by themselves and retain housing that is decent, safe, and sanitary. ${ }^{99}$

93. HHFA, ReLocation Data 15.

94. Ibid.

95. HHFA, URM § 16-2-1, at 3.

96. Some self-relocatees may have moved before being contacted by the relocation staff, as there is often an interval between approval and execution of a renewal project. The need for relocation advice at an early stage is suggested in ConNECTrcur Advisony Commr., Report on Connecticut: Family Relocation Under Urban Renewal (1963).

97. The 7500 families now known to be in substandard housing (see note 16 supra and accompanying text), are those who have refused additional relocation assistance. HHFA, Relocation Data 9-10.

98. See notes 14 and 77 supra. Section 105 (c) seems clearly to comprehend permanent relocation of site families, since it permits temporary rehousing prior to the availability of sufficient decent dwellings. Relocation in adequate but deteriorating facilities would thus seem contrary to the statutory standard.

99. See, e.g., Creighton, supra note 92 , at 31 ; Thabit, supra note 92, at 86 ; Cogen, supra note 92 , at $80-81$. These critics suggest that the loss of housing must be scheduled against new construction, perhaps on vacant land, if the renewal program is not to accumulate severe housing and relocation problems. But privately financed new construction is beyond the reach of most low and middle-income families. See Wurster, Framework for an Urban Society, in President's Commession on National Goals, Goals for Americans 225, 237 (1960). When their needs cannot be met by filtering (see note 14 supra), the community must create housing especially for them. The short-range solution seems to be the construction of low-income housing as a relocation resource. Such housing must be subsidized, either directly, in public housing, or indirectly, by financial assistance to builders or by rent supplementation, which creates among low-income families a market for privately financed housing. Since 1954, federally insured mortgages have been available under $\$ 221$ of the Housing Act for the construction of relocation housing. 68 Stat. 
In raising a challenge to the Administrator's relocation policies, then, the site family presents the court with what seems a live and significant issue of statutory interpretation. But the criticism of the relocation standard is basically a criticism of the direction which the entire renewal program has taken. When analyzed closely, the critics' basic argument is that renewal planning has departed from the original housing goals of the program with the result that little, if any, improvement is being made in the housing conditions of lowincome families. ${ }^{100}$ The attempt to secure judicial review of relocation planning may thus prove to be an attempt to secure a court-ordered re-direction of the renewal plan towards immediate realization of improved housing conditions. However strong the arguments for judicial relief from the Administrator's interpretation of section 105 (c) appear in isolation, ${ }^{101}$ they lose much of their force when that provision is read against the changing patterns of renewal which are reflected in amendments to the Housing Acts. While Congress has twice increased the scope of Title I to make possible a broadened attack on urban problems and to emphasize the importance of sound community planning, ${ }^{102}$ at the same time, it has de-emphasized the housing objectives of the program by permitting an increasing proportion of federal monies to be devoted to renewal projects having little connection with the housing problem. ${ }^{103}$ These amendments would seem to indicate that Congress

599 (1954), as amended, 12 U.S.C. \$ $1715 l$ (Supp. IV 1962). Under $\$ 220$, mortgages have been available to finance rehabilitation and new construction in urban renewal areas. 68 Stat. 596 (1954), as amended, 12 U.S.C. $\$ 1715 k$ (Supp. IV 1962). Locally financed rent supplementation is permitted under HHFA regulations. HHFA, URM $\$ 16-1$, at 2 , $\$ 16-2-1$, at 2. It has been tried in some localities, see, e.g., New Haven Register, Jan. 29,1964 , p. 1, col. 1, and recommended in some others. See, e.g., N.Y. Times, Sept. 25, 1963, p. 1, col. 7. An experimental plan to make more housing available to low-income families calls for placing them in vacant houses, with government bearing the cost differential. N.Y. Times, Jan. 12, 1964, p. 1, col. 3.

100. See, e.g., Grigsby, supra note 92; Meltzer, supra note 92, at 452-53.

101. See notes $92-99$ supra and accompanying text.

102. In 1954, Congress inaugurated the renewal concept (see notes 4-5 supra and accompanying text) and introduced the Workable Program, which was designed to bring about coordinated, long-range renewal programming. 68 Stat. 627 (1954), as amended, 42 U.S.C. \$ 1451 (c) (Supp. IV 1962). In 1959, Congress further emphasized the importance of coordinated renewal planning by directing the HHFA to encourage renewal planning on a metropolitan or regional scale. 73 Stat. 670 (1959), as amended, 42 U.S.C. $§ 1451$ (b) (Supp. IV 1962).

103. Under the 1949 Act, Title I assistance was available only to redevelopment projects which were predominantly residential before or after redevelopment. 63 Stat. 420 (1949). In 1956, this requirement was relaxed to permit assistance to projects not predominantly residential, but which contained a "substantial number" of blighted dwellings. Up to $10 \%$ of Title I funds could be spent in this manner. 70 Stat. 1098 (1956). In 1959, the limitation on the amount of capital grants for areas not predominantly residential was increased to $20 \%$. Moreover, the 1959 act permitted the award of such funds if the community governing body determined that the project was necessary to achieve local renewal goals and eliminated the requirement that the non-residential area contain a substantial amount of blighted housing. 73 Stat. 675 (1959). In 1961, the percentage of Titie I assistance available for non-residential projects was increased to $30 \% .75$ Stat. 168 
has at least temporarily abandoned the original housing goals of Title $I$ in order to permit renewal communities to give first priority to restoring their economic structure. ${ }^{104}$ Moreover, the Administrator has from the beginning adhered to his present interpretation of section 105(c), ${ }^{105}$ and Congress has not seen fit to amend that provision. This background of statutory development suggests that the present pattern of renewal programming coincides with legislative purpose. Because the Administrator's interpretation of section 105 (c) seems consistent with congressional intent, a court today can offer little relief to a site family who alleges that the Administrator has wrongly interpreted section 105 (c). But the fact that a court seems limited by present circumstances in its ability to grant relief should afford no justification for its denying standing or review to a complaining displacee. Not only is Congress free to revise the standards for relocation and renewal planning, but the Administrator may act in an arbitrary manner in a particular case or, more generally, may adopt another interpretation of the statute. In such circumstances, a court might well find that administrative practice did not conform to legislative purpose. That the court should then intervene to reconcile practice and purpose seems the justification for its considering the merits of every allegation that the two are in discord.

(1961), 42 U.S.C. \$ 1460(c) (Supp. IV 1962). Even under the 1949 standard, however, communities were free to concentrate on projects which replaced slum neighborhoods (predominantly residential) with commercial facilities.

104. See note 75 supra.

105. From time to time, the HHFA has revised the details of its relocation requirements, but the underlying policies have not changed. An examination of the HHFA, URM indicates the frequency of revision. 